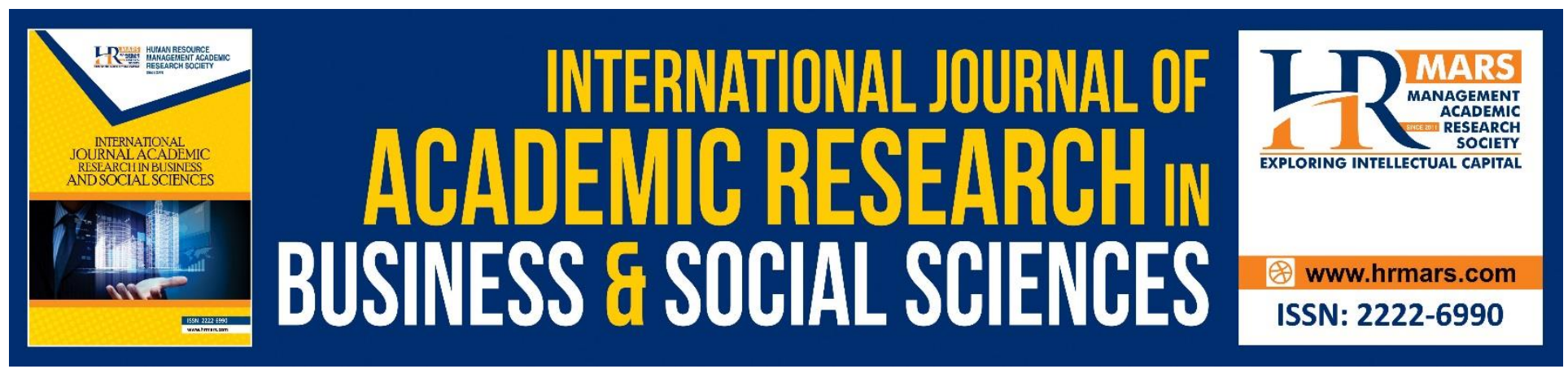

\title{
Factors Affecting Consumers' Intention to Purchase Counterfeit Products in Fashion Industry
}

\section{Muhammad Amirul Hanif B Md Yunos, Masri Bin Abdul Lasi}

To Link this Article: http://dx.doi.org/10.6007/IJARBSS/v10-i10/8013 DOI:10.6007/IJARBSS/v10-i10/8013

Received: 04 August 2020, Revised: 24 August 2020, Accepted: 16 September 2020

Published Online: 25 October 2020

In-Text Citation: (Yunos, \& Abdul Lasi, 2020)

To Cite this Article: Yunos, M. A. H. B. M., \& Abdul Lasi, M. Bin. (2020). Factors Affecting Consumers' Intention to Purchase Counterfeit Products in Fashion Industry. International Journal of Academic Research in Business and Social Sciences. 10(10), 939-949.

\section{Copyright: (c) 2020 The Author(s)}

Published by Human Resource Management Academic Research Society (www.hrmars.com)

This article is published under the Creative Commons Attribution (CC BY 4.0) license. Anyone may reproduce, distribute, translate and create derivative works of this article (for both commercial and non-commercial purposes), subject to full attribution to the original publication and authors. The full terms of this license may be seen

at: $\underline{\text { http://creativecommons.org/licences/by/4.0/legalcode }}$

\section{Vol. 10, No. 10, 2020, Pg. 939 - 949}

Full Terms \& Conditions of access and use can be found at http://hrmars.com/index.php/pages/detail/publication-ethics 


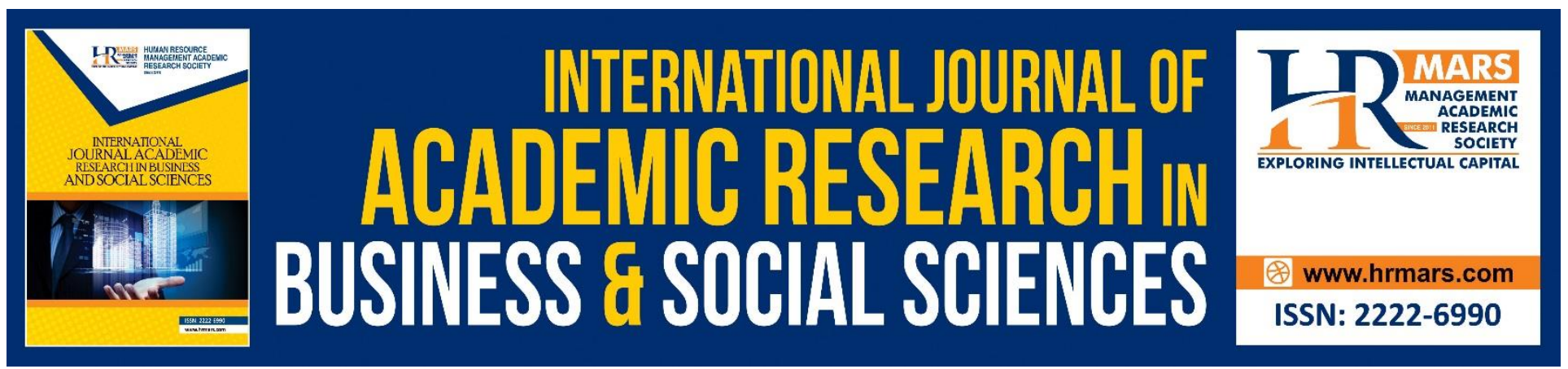

\title{
Factors Affecting Consumers' Intention to Purchase Counterfeit Products in Fashion Industry
}

\author{
Muhammad Amirul Hanif B Md Yunos ${ }^{1}$, Masri Bin Abdul Lasi ${ }^{2}$ \\ ${ }^{1}$ City Graduate School, City University, Malaysia, ${ }^{2}$ City Graduate School, City University, Malaysia \\ Email: hanhanif580@gmail.com,masri.abdullasi@city.edu.com
}

\begin{abstract}
The purpose of this study is to examine the factors affecting consumers' intention to purchase counterfeit products in fashion industry and the way does it affect the consumers' intention. During this research, data were gathered from a sample of 200 individual respondents which was distributed randomly with minimum age of 18 years old and above. By employing a sample of 200 respondents with 27 set of questions, the study identified five factors that affect consumers' intention to purchase counterfeit products in rag trade like brand, price, attitude, social influence and demographic. The results revealed that price factors has the strongest relationship with consumers' intention to purchase counterfeit products and social influence can even considered because the most vital factor affecting consumers' intention further .The third and fourth most vital factors affecting consumer's intention to buy counterfeit products is brand and demographic factors. The results also indicated that although attitude is one in every of the factors but it shows that the attitude somehow is that the least important factor among the five factors identified during this study. These factors also will help the organizations or brand owner to know and concern more about the opinion of those group of consumer. Lastly, limitations and proposals ways on how consumer and brand owner to avoid from becoming the victims of counterfeiting.
\end{abstract}

Methodology: In this research, exploratory analysis through the survey questionnaire was implemented using convenience sampling process. The information was analyzed using descriptive analyses yet as normality and comparison evaluates the information in this study were collected from a sample of 200 respondents.

Findings: The empirical survey data analysis on distinguish five key important factors affecting consumers' intention to purchase counterfeit products in fashion industry, namely brand, price, attitude, social influence and demographic. Through the research that has been conducted, it had been found that buyers aware of the counterfeit issue in fashion industry but major factors in and of itself price, social influence and also demographic contribute to those issue to spread more to the entire a part of world which is sort of sad to work out this issue happened when consumers doesn't know how difficult for the brands to be well-known but at the top the products of the brand being counterfeit by those irresponsible party. 
INTERNATIONAL JOURNAL OF ACADEMIC RESEARCH IN BUSINESS AND SOCIAL SCIENCES Vol. 10, No. 10, 2020, E-ISSN: 2222-6990 @ 2020 HRMARS

Conclusion and Recommendations: The study concluded that the five factors affecting consumers' intention shown a robust relationship during this study whereby price is the major problem when it involves purchase the counterfeit products. Recommendations for future researchers are hints at the end of this study.

Keywords: Counterfeit, Consumer Intention, Factors Affecting, Price, Social Influence, Brand, Attitude, Demographic.

\section{Introduction}

Market counterfeiting is not a common problem where we can't just close our eyes and not pay attention to this issue because many fashion industry-focusing brands around the world have been affected by this issue. Counterfeiting may have a strong effect on different groups, such as corporation, governments and individuals, which includes property law, criminal law, administrative law, which civil law, affects intellectual rights. Counterfeiting is defined as the manufacture of products identical to the original product, including trademarks, labels and packages presumed to be a genuine product for the consumer (Patiro \& Sihombing, 2016) Counterfeiting in fashion industry is an active business practice, many companies keep track of counterfeiting because it not only affects their brand image, but economic interests are the most relevant. Five factors identified consists of brand, price, social influence, attitude and demographic.

\section{Literature Review}

Demand for the purchase of counterfeit goods is rising day after day due to numerous factors (Quoquab et al., 2017). Due to the increasing number of counterfeit items on the market, the interest of customers to purchase these counterfeit products is also increasing (Bhatia, 2018). The global fashion industry would be the seventh largest economy in the world if countries were ranked by GDP (The State of Fashion, 2017). We can say that the intention to purchase is a subjective judgment of the person willing to perform a particular counterfeit purchase behavior (Chiu and Leng, 2016) . According to Mramba (2015), consumers' purchase decisions are influenced by many factors, and the same for personal, psychological, social and cultural factors, making it difficult for marketers to predict how consumers buy a particular product. This include the five factors such as brand, price, attitude, social influence and demographic.

\section{Brand Factors}

Consumers in the fashion industry will indeed start by looking up to either the brand when it's time for them to make a purchase decision. Previous researchers have found out that a brand name is a crucial element of brand loyalty and is also considered a precondition for the buying decision of customers ( $\mathrm{Wu}, 2015)$. Throughout many ways, brand is represented in a personification and semipersonalization approach with various abilities (Mete and Davies, 2017). The brand image influences purchasing decisions greatly (Djatmiko and Pradana, 2015).

\section{Price Factors}

The price-consumer relationship can also be taken into consideration. Price factors are the support of earlier researchers one of which mentioned that demand from the market for these counterfeits items was mainly due to its lower costs than its initial price (Chiu \& Leng, 2016). In addition, price in 
INTERNATIONAL JOURNAL OF ACADEMIC RESEARCH IN BUSINESS AND SOCIAL SCIENCES Vol. 10 , No. 10, 2020, E-ISSN: 2222-6990 @ 2020 HRMARS

particular for products often bought, is a major factor in the buying decision, and it also influences the choice which store, product and brand to buy (Faith and Agwu, 2014).

\section{Attitude Factors}

The attitude of consumers today, particularly in terms of fashionability, will not concern consumers with the originality of products. Loyal customers are usually proactive (Habibi, Laroche, \& Richard, 2014a) . These studies are evidence that the intentions are the projections of actual behavior (Rahimah et al. 2018). The consumer attitude which lead to counterfeit buying behaviours, differ among these markets. In consumer literature, the correlation between attitude and intention was widely examined (Erkan \& Evans, 2016; Lee, 2016). The theory of planned behavior (TPB) which states the individual's intention to perform a given behavior (Ajzen , 1991) is a supporting theory which can be seen.

\section{Social Influence Factors}

These factors may become the main factors as consumers who can purchase counterfeit products are involved. Amaral and Loken (2016) have explained that the majority of higher class consumers tends to demean the mark when lower classes use counterfeit brand versions, but lower classes tend not to demean when higher classes use counterfeit versions. Djuhardi and Kusumawati (2017) stated that attitude had a major influence on consumers behavior.

\section{Demographic Factors}

The demographics in this area include age, gender and income levels in order to determine their respective intentions. Previous studies found few factors affecting demographic buying intention for counterfeit goods based on country, country generation and value perception (Bhatia, 2018; Fastoso et al ., 2018; Bachmann et al . , 2018; Jiang \& Shan, 2018). In addition, few studies were identified as factors that lead to counterfeit purchasing intentions as a general point of view (Mir et al . 2012; Rizwan et al. 2014), gender (Chen \& Tang, 2006).

\section{Research Methodology}

In this study, the statistical package for social science ( SPSS ) software was used to analyze data using a quantitative method. A survey questionnaire prepared includes questions that have been developed for study purposes. These questionnaires have been circulated to random respondents aged at least 18 years and older. Technically, it was because the demographic perspectives such as age, gender, and even the occupation of the respondents are different. 
INTERNATIONAL JOURNAL OF ACADEMIC RESEARCH IN BUSINESS AND SOCIAL SCIENCES

Vol. 10, No. 10, 2020, E-ISSN: 2222-6990 @ 2020 HRMARS

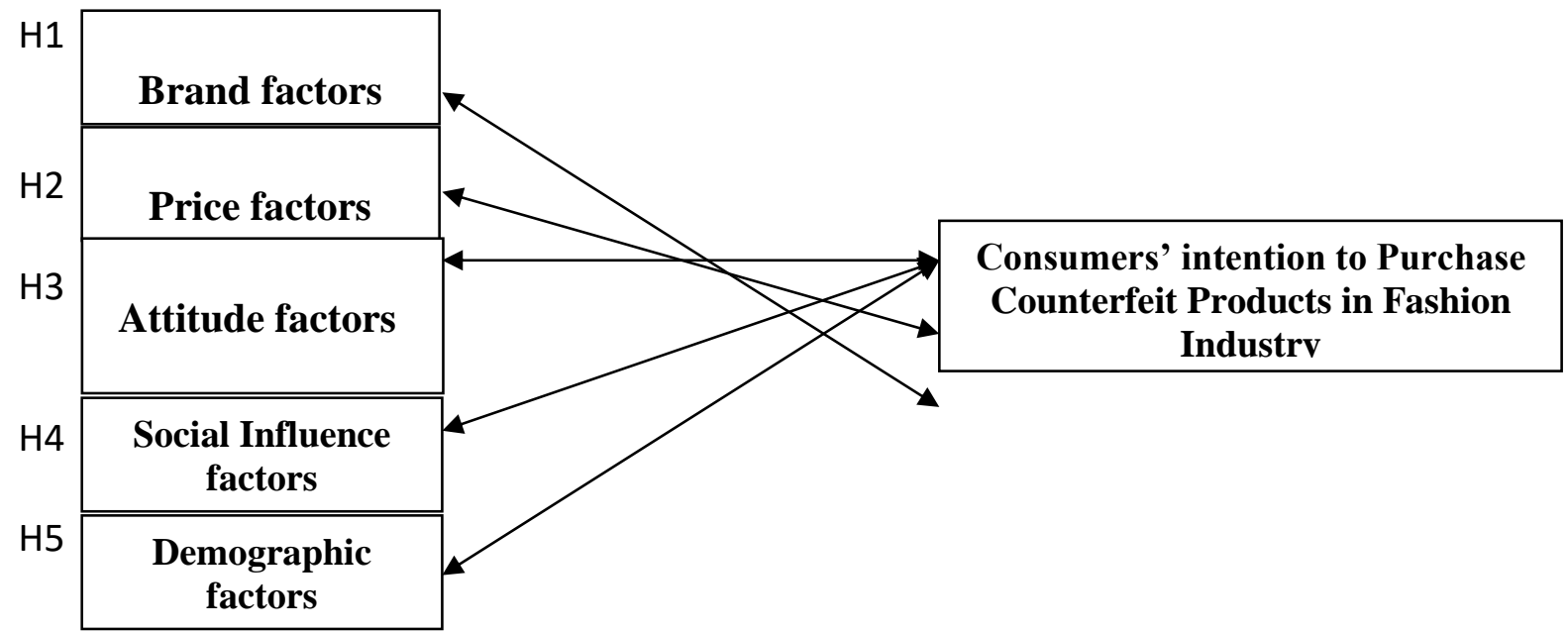

Diagran 3 shows a research framework for this study

The independent variables for this research have been identified as the factors affecting while dependent variable studied as consumers' intention to purchase counterfeit products in fashion industry. These factors affecting consumers' intention were categorized into five elements namely, brand, price, attitude, social influence and demographic. The research framework illustrated as shown in Diagram 3

\section{Research Hypothesis}

Based on the study, the following hypotheses were developed in this study:

$\mathrm{H} 1$ : Brand factors has a positive relationship with the consumers' intention to purchase counterfeit product in fashion Industry

$\mathrm{H}$ 2: Price factors of counterfeit product has a positive relationship with the intention to purchase counterfeit products in fashion industry.

H3: Attitude factors has a positive relationship with the intention to purchase counterfeit products in fashion industry.

$\mathrm{H}$ 4: Social influence factors has a positive relationship with the intention to purchase counterfeit products in fashion industry.

H5: Demographic factors has a positive relationship with the intention to purchase counterfeit products in fashion industry.

\section{Results and Discussion}

In this analysis, the number of respondents taken is 200, based on the demographic characteristics of the respondents. This leads in a majority of respondents in the age group between 22 to 29 years old. The proportion of men is 36 percent and females is 64 percent. 


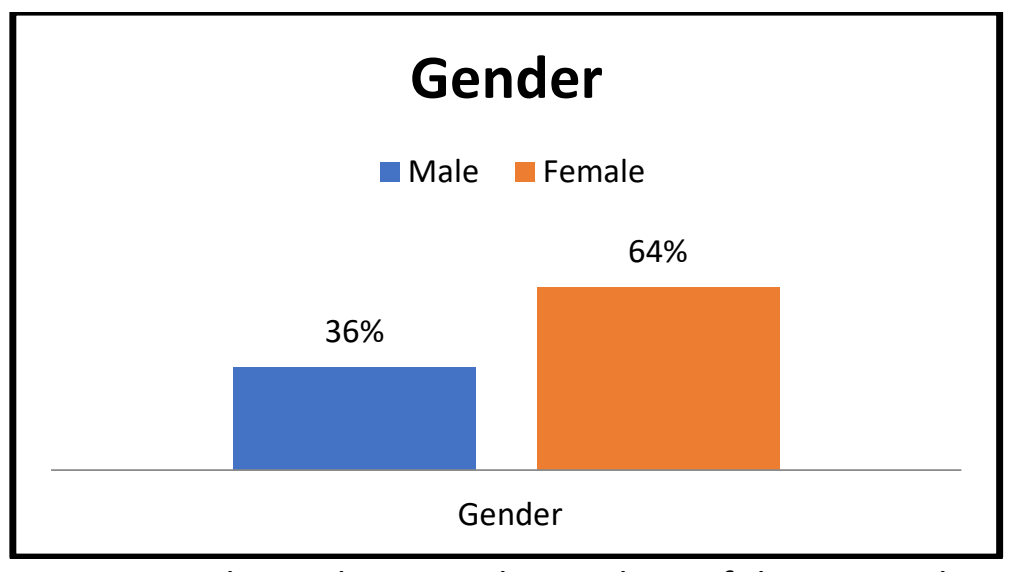

Figure 2 shows demographic analysis of the respondents

The five hypotheses were discussed and performed based on the factor analysis which are now being considered in line of the literatures reviewed.

H1: Brand factors has a positive relationship with the consumers' intention to purchase counterfeit product in fashion Industry.

According to the survey, $70 \%$ agreed that brands represent one of the factors which influences the intention of consumers to purchase counterfeit products in the fashion industry. When the customer purchases any type of product, the brand looks at the products themselves. Kotler and Armstrong (2014) also explained that the decision to buy a brand to purchase is an acquisition decision. In addition, most of the consumers do not usually have time when making a purchasing decision to obtain full knowledge of a product.

According to the survey, $77 \%$ said that fake products could be recognized, and $13 \%$ said that fake fashion products or brands could not be distinguished. From above, it can be concluded that the respondents are the loyal consumer group which is concerned with the brand as they are able to identify the fake brand products. Consequently, consumers generally rely on the brand image for purchase decisions as a behavioral motif (Lin, 2007; Duranni et al., 2015; Akkucuk dan Esmaeili, 2016). In addition, the finding can conclude that brand factors always play a vital role in the intention of consumers. It is also a way of raising the awareness, promotion and other marketing activities of the fashion brands to attract consumers to purchase the items.

Study shows that Spearment's rho between factors affecting and brand is 0.932 meaning that positive linear relationship in two variable showing brand one of major factors affecting consumers' intention to purchase counterfeit products in fashion industry. The hypothesis of brand factors also is positive with the intention of consumers to buy counterfeit goods in the fashion industry.

H2: Price factors of counterfeit product has a positive relationship with the intention to purchase counterfeit products in fashion industry.

The price has an important role in the purchasing decision, particularly for the products that are often bought and which, at the same time, influence the choice of which shops, products and brands are to be treated badly (Faith and Agwu, 2014). The finding shows that (80\%) of the responses strongly agree that price factors have influence on the purchase of fashion-related products. One of the top 
INTERNATIONAL JOURNAL OF ACADEMIC RESEARCH IN BUSINESS AND SOCIAL SCIENCES Vol. 10, No. 10, 2020, E-ISSN: 2222-6990 @ 2020 HRMARS

five factors showed above findings Clearly, the respondents are positive, as if the price is higher, they cannot buy the products and this could also influence the consumer to switch into fake products of the same brand. Many consumers will use price as a quality indicator (Lien et al., 2015), as the conventional saying "You get what you pay for." This survey can relate above theory, with $77 \%$ saying they will purchase the counterfeit if the price becomes less expensive than the original product. Price in the counterfeiting industry is certainly crucial.

Study shows that Spearment's rho between factors affecting and price is 0.945 meaning that positive linear relationship in two variables showing price one of major factors affecting consumers' intention to purchase counterfeit products in fashion industry. As such, the hypothesis has shown that price factors are positive for the intention to buy fashion products.

H3 : Attitude factors has a positive relationship with the consumer's intention to purchase counterfeit products in fashion industry.

Various factors shape people's behavior, leading them to buy fake brands (Chiu \& Leng, 2016). According to research, $78 \%$ strongly agreed that the consumer wants to purchase counterfeit products with attitude factors. $73 \%$ agreed that the reason the consumer bought the fashion industry's counterfeits, which follow the trend, attract attention and be trendy, was to support of that kind research findings. Many such studies indicate that the intention is always to projection actual conduct ( Rahimah et al., 2018). Eventually, as mentioned above, it is acceptable that consumers who purchase counterfeit products should be influenced by their own personal family or friends. This could be because of the consumer's thinking about the brand that satisfies the needs. Study shows that Spearment's rho between factors affecting and attitude is 0.925 meaning that positive linear relationship in two variable showing attitude one of major factors affecting consumers' intention to purchase counterfeit products in fashion industry

The hypothesis has shown that the behavioral factors relate positively to the intent to purchase fashion products.

H4 : Social influence factors has a positive relationship with the consumer's intention to purchase counterfeit products in fashion industry.

These factors may become the main factors as consumers who can purchase counterfeit products are involved. The people around us have a great impact on our behavior, personal preferences. We always ask people around us for confirmation, and rarely do things that are unacceptable to society. The survey result shows, $85.5 \%$ of those surveyed were strongly in agreement on social impact factors affecting consumer intention to purchase fashion products.

As an example, the rich people have the ability to purchase more products than the low-income people, and these goods are of higher quality. The type of goods purchased also differentiates. For example, high-end group of consumer are always the purchase shoe often at anywhere from luxury outlet, shop or retailers and some may shop through online. The lower class is much more interested only in getting the products through which they concentrate more on needs. In addition, we can also discuss about how peers and families, with many potential to redirect negatives and increase positive effects, are able to provide an opportunity to social adaptation. In this situation, Amaral and Loken (2016) explained that higher-class consumers tend to denigrate brands when lower-class consumers 
INTERNATIONAL JOURNAL OF ACADEMIC RESEARCH IN BUSINESS AND SOCIAL SCIENCES Vol. 10, No. 10, 2020, E-ISSN: 2222-6990 @ 2020 HRMARS

use fake versions of the brand but lower-class consumers tend not to denigrate when higher-class customers use the fake-class versions of the brands.

In relation, $45 \%$ of the respondents said that their friends influenced social factors, and $30 \%$ replied to personal preference when decision-making was necessary. The results also found that $29,6 \%$ of responses to perhaps recommend the counterfeit products to one of their friends or family members. The number is quite vast as the purchase may be agreed upon, but somehow depends on the situation such as product suitability, reliability and durability. Study shows that Spearment's rho between factors affecting and social influence is 0.936 meaning that positive linear relationship in two variables showing social influence one of major factors affecting consumers' intention to purchase counterfeit products in fashion industry. Thus, the hypothesis proven that social influence factors has a positive relationship with the consumers' intention to purchase counterfeit products in fashion industry.

H5 : Demographic factors has a positive relationship with the intention to purchase counterfeit products in fashion industry.

Uncertain effects on identity building through buying behavior could become demographic factors. Gender could influence counterfeit consumption as an example of this situation. Age is an important demographic factor that affects consumer behavior. The finding shows that $87 \%$ demographic responses to age lead to consumer intention in the fashion sector to buy counterfeit products. Age changes affect their needs and personal values, such as lifestyle. Another example of the situation would be young people, who will expend more on their lifestyle needs, from fun and fashion to films. As they grow older, their costs decrease.

The large number of elderly people remain indoors, but health expenses can also increase. Age is one of the key population factors influencing the intention of the consumer to purchase counterfeit products in the fashion industry. Based on our finding, $90 \%$ agreed that income is one of demographic factors which contribute to the consumers ' intention to purchase counterfeit products in fashion industry. Also most consumers are or are not so aware of the brand.

According to (Stephen et al., 2014) which concluded that low earners are more likely to purchase counterfeit products. Study shows that Spearment's rho between factors affecting and demographic is 0.919 meaning that positive linear relationship in two variables showing demographic one of major factors affecting consumers' intention to purchase counterfeit products in fashion industry. Thus, the hypothesis proven that demographic factors has a positive relationship with the consumers' intention to purchase counterfeit products in fashion industry.

\section{Conclusion}

In short, the fashion industry is inherently connected with productivity growth. If the country were to hold GDP (The State of Fashion, 2017), the world fashion industry would become the 7th largest economy in the world. In fact, luxury clothing is considered a necessity of fashion in this contemporary world (The State of Fashion, 2017; Business Wire, 2017a). Counterfeit products have recently been detected as a serious issue worldwide. The purchase of counterfeit products may affect the economy and the entire consumer in different ways. Thus, in this illegal activity, sales of 
INTERNATIONAL JOURNAL OF ACADEMIC RESEARCH IN BUSINESS AND SOCIAL SCIENCES Vol. 10, No. 10, 2020, E-ISSN: 2222-6990 @ 2020 HRMARS

counterfeit products are not only damaging to the world that affects brand image, but also to terrorist financing and other criminal activities.

To conclude, this study has taken on various factors to identify factors affecting the intent of consumers to buy fashion counterfeit goods. Even if counterfeit consumption is one of the greatest challenges in both developing and global areas, factors like pricing, brand social impact, attitudes and the demographics have still to be taken into account. The study has thus found critical insights based on different factors affecting consumer intention on fashion-related products. The owner of the brand, the price, the social influence, and the demographic factors of consumer purchasing decisions is also recommended to concentrate on the brand's marketing strategies and plans.

Here are some recommendations for the original brands producers should not try to profit to the maximum extent by increasing prices for each of their products. Price is the main factor in promoting counterfeit products for consumers. Secondly, they should develop such designs that the manufacturers of counterfeit products could not easily copy them. Finally, by helping the government to inform and educate people that counterfeit products are illegally and unethical, they should come forward with certain legal legislation.

Furthermore, awareness of counterfeits is increased. The company states, for example, that it adopts a zero tolerance policy and takes action not only with regard to websites that offer counterfeit products but also against distributors of counterfeit products, auction sites and other distribution channels. Apart from this, counterfeit products are fitted with microchips. Every piece of clothing contains a small RFID that contains one unique identity which permits the consumer to scan the chip using a Smartphone or by registering on the official website of the brands when the consumer does not have a Smartphone.

Numerous ways for the brand owner to capture the intention of the consumer, probably by showing a good public value for the brand, are possible. Besides that it is possible for the brand owner to display its ethnic and moral value when offering complementary products to new customers. Branding is an important factor in attracting the attention of consumers. Brand history, social activities and any programs that will make the consumer feel more involved in the brand, which will support the fake products in the future. Other brands might in the future use this method, like inserting a micro ship, to enable the company to verify its authenticity.

These chips serve not only to verify for consumers whether they bought the original product because the owners of the brand can also verify whether suppliers illegally sell an excess inventory on the market. So much can be done to prevent the brands from being subjected to counterfeit products. There are thus few other ways to avoid becoming the next victim. Develop a multi-stakeholder strategy essentially involves brand safety and needs a multi-stakeholder strategy including the materials. This is necessary for businesses owner to realize that a strategy implementation and tactic to protect own brand is important to start. In addition, list all the production and distribution elements, from raw material purchasing to the distribution cycle, and waste scrap and waste management, including the analysis of guarantees and claims, to stay ahead. Brand integrity audits are necessary in this part of this strategy to evaluate the competitive level of new products and to assess the level of counterfeiting activities in an industry where all products are sold. Government 
INTERNATIONAL JOURNAL OF ACADEMIC RESEARCH IN BUSINESS AND SOCIAL SCIENCES Vol. 10, No. 10, 2020, E-ISSN: 2222-6990 @ 2020 HRMARS

should warn that the purchase of fake goods in travel notices issued to its citizens by Governments will slowly and surely decrease the number of fake products, for example, that also informs consumers about fake goods and what counterfeits are made, anywhere and everywhere consumers purchase quality products information .

\section{Limitation of the Study}

This research covers certain limitations. First, a cross-sectional design had been adopted for research, which could not confirm the causal evidence of both the variables used. Secondly, this report used just five factors, as discussed previously, to evaluate the decision to purchase counterfeit luxury, although the intention to buy counterfeit products in the furniture industry was expected to examine only the factors of these factors. Future research could take quite few variables to end up making respondents more reasonably evaluate the various determining factors and help researchers to achieve more accurate results than before.

Data from a small population have been obtained which limits the findings generally for others. The results of this study have raised certain crucial insights into the purchase decision for fashion-based counterfeit products and can be capitalized by the replication of specific products and population groups. Research can be carried out in accordance with the category of product, including products of luxury, shopping and convenience. Through an analysis of the influences of the various factors on the intention to purchase counterfeits, the issues are expected to rationally assess future research findings.

\section{References}

Al-Mamun, A., and Rahman, M. K. (2014). a Critical Review of Consumers' Sensitivity to Price: Managerial and Theoretical Issues. Journal of International Business and Economics, 2 (2), 01 09

Ajzen, I. (1991). The theory of planned behavior. Organizational Behavior and Human Decision Process, 50(2), 179-211. https://doi. org/10.1016/0749-5978(91)90020-T

Akkucuk, U., and Esmaeili, J. (2016). The Impact of Brands on Consumer Buying Behavior: An Empirical Study on Smartphone Buyers. Turkey Journal of Research in Business \& Social Science, 5 (4), 01-16

Bhatia, V. (2018). Examining consumers' attitude towards the purchase of counterfeit fashion products. Journal of Indian Business Research, 10(2), 193-207.

Bhatia, V. (2018). Examining consumers' attitude towards the purchase of counterfeit fashion products. Journal of Indian Business Research, 10(2), 193-207

Bian, X., and Moutinho, L. (2008). The Role of Brand Image, Product Involvement, and Knowledge in Explaining Consumer Purchase Behaviour of Counterfeits Direct and Indirect Effects. Research Memorandum, 77 (March), 1-34

Buehler, S., and Halbherr, D. (2017). Selling When Brand Image Matter. Journal of Institutional and Theoritical Economics, 167 (1), 102- 118

Chiu, W., \& Leng, H. K. (2016). Consumers' intention to purchase counterfeit sporting goods in Singapore and Taiwan. Asia Pacific Journal of Marketing and Logistics, 28(1), 23-36. https://doi.org/10.1108/ APJML-02-2015-0031

Djatmiko, T., and Pradana, R. (2015). Brand Image and Product Price: Its Impact for Samsung Smartphone Purchasing Decision. Procedia Social and Behavioral Sciences, 221-227 
INTERNATIONAL JOURNAL OF ACADEMIC RESEARCH IN BUSINESS AND SOCIAL SCIENCES Vol. 10, No. 10, 2020, E-ISSN: 2222-6990 @ 2020 HRMARS

Durrani, B. A., Godil, D. I., Baig, M. U., and Sajid, S. (2015). Impact of Brand Image on Buying Behaviour Among Teenagers. European Scientific Journal, 11 (51), 155-168

Faith, D. O., and Agwu, M. E. (2014). a Review of the Effect of Pricing Strategies on the Purchase of Consumer Goods. International Journal of Research in Management, Science \& Technology, 2 (2), 88-102

Lin, N. H. (2007). The Effect of Brand Image and Product Knowledge on Purchase Intention Moderated by Price Discount. Journal of International Management Studies, August, 121-132

Mir, I. A., Rizwan, M., \& Saboor, F. (2012). Pricing and accessibility impact on young consumers' attitude towards non-deceptive counterfeits and their purchase intentions: a case of Pakistani mobile phone market. Actual Problems of Economics, 4, 406-414

Mramba, N. R. (2015). Does the Brand Name Matter to Purchase Decision? The Case of Mobile Phone. European Journal of Business and Management, 7 (4), 335-343

Patiro, S. P. S., \& Sihombing, S. O. (2016). Predicting intention to purchase counterfeit products: extending the theory of planned behavior. International Research Journal of Business Studies, $7(2), 109-120$.

Quoquab, F., Pahlevan, S., Mohammad, J., \& Thurasamy, R. (2017). Factors affecting consumers' intention to purchase counterfeit product: empirical study in the Malaysian market. Asia Pacific Journal of Marketing and Logistics, 29(4), 837-853.

Available at : https://doi.org/10.1108/ APJML-09-2016-0169

Sharma, P., \& Chan, R. Y. K. (2017). Exploring the role of attitudinal functions in counterfeit purchase behavior via an extended conceptual framework. Psychology \& Marketing, 34(3), 294-308.

Vogel, A. T., and Watchravesringkan, K. (2017). Consumer Evaluation of Trend Imitation: Brand Equity, Consumer Attitudes and Preference. Journal of Product and Brand Management, 26 (5), 516-527.

Wu, C. S. (2015). a Study on Consumers' Attitude Towards Brand Image, Athletes' Endorsement, and Purchase Intention. The International Journal of Organizational Innovation, 8 (2), 233-25 